\title{
Pengaruh Variasi Konsentrasi Tepung Kedelai sebagai Bahan Pengikat terhadap Kadar Air dan Mutu Organoleptik Nugget Ikan Gabus (Ophiocephalus Sriatus)
}

\author{
Soybean Flouras a Contribution to The Binder Water Content and \\ Organoleptic Quality Nugget Fish Cork (Ophiocephalus sriatus) \\ Yenni Ofrianti, Jamila Wati \\ Jurusan Gizi Poltekkes Kemenkes Bengkulu \\ Jalan Indragiri No. 3 Padang Harapan, Bengkulu, Telp (0736) 341212
}

\begin{abstract}
This research aims to look at influence of addition soybean flourin the manufacture of cork fish nuggets (Ophiocephalus Sriatus) on water content and organoleptic quality. This research is an experimental study using a completely randomized design (CRD). The results showed that there was no influence of the addition of soy flour to the water content of the fish nuggets cork. There is no effect ofthe addition of soybean flour with organoleptic quality (color attribute) $(\mathrm{Q}>0.05)$. And there is an effect $\mathrm{o}$ fthe addition of soybean flour to the organoleptic quality (taste and texture attributes) ( $\mathrm{e}<0.05$ ). Research was can be continued with the addition of soybean flour concentration influences the shelf life nugget.
\end{abstract}

Keywords: soybean flour, nuggets, water content, organoleptic

\begin{abstract}
ABSTRAK
Penelitian ini bertujuan untuk melihat pengaruh penambahan tepung kedelai pada pembuatan nugget ikan gabus (Ophiocephalus Sriatus) terhadap kadar air dan mutu organoleptik. Penelitian ini merupakan penelitian eksperimen dengan menggunakan rancangan acak lengkap (RAL). Hasil penelitian menunjukkan bahwa tidak ada pengaruh penambahan tepung kedelai terhadap kadar air nugget ikan gabus. Tidak ada pengaruh penambahan tepung kedelai dengan mutu organoleptik (atribut warna) $(\varrho>0,05)$. Serta ada pengaruh terrhadap penambahan tepung kedelai dengan mutu organoleptik (atribut rasa dan tekstur) (@ < 0,05). Penelitian ini dapat dilanjutkan dengan pengaruh konsentrasi penambahan tepung kedelai terhadap daya simpan nugget.

Kata Kunci: Nugget, Bahan Pengikat, Kedelai, Ikan Gabus
\end{abstract}




\section{PENDAHULUAN}

Masalah gizi pada hakikatnya
adalah masalah masyarakat, namun penanggulangannya tidak dapat dilakukan dengan pendekatan medis dan pelayanan kesehatan saja.Penyebab timbulnya masalah gizi adalah multifaktor, oleh karena itu pendekatan penanggulangannya harus melibatkan beberapa sektor yang terkait (Supariasa dkk, 2001). Salah satu masalah gizi di Indonesia adalah Kurang Energi Kronik (KEK) pada ibu hamil. Kekurangan Energi Kronik (KEK) adalah keadaan dimana seseorang mengalami kekura-ngan gizi (energi dan protein) yang berlangsung lama atau menahun (Chinue, 2009 dalam Nur, 2010).

KEK perlumengalami penanganan yaitu dengan pemberian maka-nan tambahan melalui penganeka-ragaman pangan. Penganekaragaman pangan adalah upaya untuk menganeka-ragamkan pola konsumsi pangan masya-rakat dalam rangka meningkatkan mutu gizi makanan yang di konsumsi yang pada akhirnya akan meningkatkan status gizi (Almatsier, 2003). Salah satu produk pangan yang berkembang di masyarakat adalah nugget.Nugget dapat dijadikan cemilan bagi ibu hamil.Nugget adalah suatu bentuk produk olahan daging yang tebuat dari daging giling yang dicetak dalam bentuk potongan persegi empat dan dilapisi dengan tepung berbumbu (baterred dan braded). Pada pembuatan nugget memerlukan beberapa proses, antara lain pengukusan dan penggorengan. Pengukusan akan me-nyebabkan pengeluaran cairan pada daging terutama pada daging yang memiliki kandungan lemaknya sangat sedikit. Hal ini akan mempengaruhi kelezatan dan nilai gizi dari nugget, sehingga perlu dilakukan penambahan bahan pengikat.

Bahan pengikat adalah material bukan daging yang dapat mengikat daya ikat air daging dan emulsifikasi lemak. Bahan pengikat mengandung protein tinggi, terutama berasal dari susu kering dan produk kedelai, misalnya tepung kedelai (Soeparno, 2005). Penambahan bahan pengikat ke dalam emulsinugget disamping sebagai bahan pengikat dan pengisi juga untuk menarik air, memberi warna dan membentuk tekstur padat (Tanikawa, 1963).Kegunaan penam-bahan bahan pengikat adalah mening-katkan daya ikat air produk daging, mengurangi pengerutan selama pemasa-kan, meningkatkan stabilitas emulsi, meningkatkan flavour dan meningkatkan karateristik irisan produk (Soeparno, 2005). Menurut Standar Nasional Indo-nesia, dalam pembuatan nugget batas maksimum kadar air adalah 60\%. Untuk mendapatkan kadar air yang mendekati Standar Nasional Indonesia pada nugget, maka 
dilakukan penambahan bahan pengikat yaitu tepung kedelai dengan menggunakan variasi konsentrasi $10 \%$, 15\% dan 20\%. Tepung kedelai adalah hasil olahan dari kacang kedelai, yang mengandung energi 347 kkal, protein 35,9 gr, lemak 20,6 gr, dan karbohidrat 29,9 gr (DKBM, 2005).

Salah satu bahan yang dapat digunakan dalam pembuatan nugget adalah ikan gabus (Ophiocephalus Striatus). Ikan gabus merupakan salah satu ikan air tawar yang memiliki kandungan protein yang paling tinggi, yaitu sebesar $25 \%$ dan memiliki kadar albumin sebesar 6,2\%, dengan kadar lemaknya yang sangat rendah (Carvallo,1998 dalam Ghufran, 2010)).Berdasarkan Daftar Komposisi Bahan Makanan (DKBM, 2005) dalam 100 gr ikan gabus mengandung 74 kkal energi, 25,2 gr protein, 1,7 gr lemak dan 0 gr karbohidrat.

Tujuan penelitian ini adalah melihat pengaruh variasi konsentrasi tepung kedelai sebagai bahan pengikat terhadap kadar air dan mutu organo-leptik nugget ikan gabus.

\section{MATERI DAN METODE}

Penelitian ini dilaksanakan di laboratorium Kimia dan Ilmu Teknilogi Pangan Poltekkes Kemenkes Bengkulu, pada bulan januari 2012. Penelitian ini meliputi beberapa tahap yaitu tahap pembuatan tepung kedelai, tahap pembuatan nugget ikan gabus, selanjut-nya nugget yang dihasilkan dianalisa kadar air dan mutu organoleptiknya.

\section{Tahap 1}

Pelaksanaan penelitian diawali dengan pengolahan kedelai menjadi tepung.Mula-mula kedelai disortasi untuk memilih kedelai yang baik, membuang benda asing dan kedelai yang rusak atau pecah.Kemudian kedelai direndam selama 8-16 jam, dan direbus 30 menit.Setelah itu, kedelai ditiriskan dan dipisahkan kulitnya.Lalu dikeringkan dengan dijemur atau menggunakan oven dengan suhu 50-60 ${ }^{\circ} \mathrm{C}$ dan digiling halus sehingga diperoleh tepung kedelai.

\section{Tahap 2}

Proses pembuatan nugget. Sortir bahan baku, pencucian bahan dari kotoran dan penirisan, timbang tepung kedelai, bumbu-bumbu dihaluskan, kemudian campur semua bahan dan bumbu-bumbu yang sudah dihaluskan dan aduk rata menggunakan food processor, masukkan ke dalam loyang dan dikukus selama 30 menit dengan suhu $60{ }^{\circ} \mathrm{C}$, setelah matang adonan didinginkan selama 30 menit supaya adonan tidak lengket, kemudian adonan dipotong-potong sesuai selera, setelah itu adonan dicelupkan ke dalam kocokan telur dan dilumuri dengan tepung roti, lalu masukkan ke 
dalam freezer selama 2 jam, kemudian panaskan minyak dalam wajan dengan suhu $150{ }^{\circ} \mathrm{C}$, kemudian goreng nugget selama 1 menit hingga matang berwarna kecoklatan, angkat dan tiriskan.

\section{Tahap 3}

Penelitian tahap 3 yaitu uji kadar air. Analisa kadar air dilakukan terhadap 3 sampel yang berbeda dan dilakukan 2 kali ulangan. Untuk mendapatkan \% kadar air menggunakan rumus. Sedang-kan uji organoleptik dilakukan untuk menilai warna, rasa dan tekstur nugget ikan gabus dengan menggunakan panelis. Penelis yang melakukan peni-laian adalah panelis agak terlatik, yaitu mahasiswa Jurusan Gizi Poltekkes Kemenkes Bengkulu tinggkat III yang berjumlah 25 orang.

\section{Rancangan Percobaan}

Penelitian ini menggunakan Ranca-ngan Acak Lengkap (RAL) dengan dua kali ulangan dan 3 perlakuan. Penelitian dilakukan dengan rancangan acak lengkap (RAL) yang dipilih karena bahan percobaan yang akan dipakai sebagai unit percobaan homogen dan jumlah perlakuan terbatas, yakni meliputi 3 macam perlakuan yaitu penambahan tepung kedelai sebanyak $10 \%, 15 \%$ dan $20 \%$. Layout penelitian yaitu:

\section{A : Konsentrasipenambahan tepung kedelai $10 \%$}

B : Konsentrasi penambahan tepung kedelai 15\%

C : Konsentrasi penambahan tepung kedelai $20 \%$

I : Nugget dengan pengulangan kadar air I

II : Nugget dengan pengulangan kadar air II

A,I : Nugget dengan penambahan tepung kedelai $10 \%$ terhadap pengulangan kadar air I

A,II: Nugget dengan penambahan tepung kedelai 10\% terhadap pengulangan kadar air II

B,I : Nugget dengan penambahan tepung kedelai $15 \%$ terhadap pengulangan kadar air I

B,II : Nugget dengan penambahan tepung kedelai $15 \%$ terhadap pengulangan kadar air II.

C,I : Nugget dengan penambahan tepung kedelai 20\% terhadap pengulangan kadar kadar I

C,II: Nugget dengan penambahan tepung kedelai 20\% terhadap pengulangankadar air II.

\section{HASIL DAN PEMBAHASAN Kadar Air}

Berdasarkan hasil penelitian dike-tahui bahwa nugget ikan gabus dengan penambahan tepung kedelai $10 \%$ memi-liki kadar air tertinggi, dapat dilihat pada tabel 1. Berdasarkan hasil Uji One Way Anova penambahan tepung kedelai 10\%, 15\% dan $20 \%$ tidak berpengaruh terhadap kadar air nugget ikan gabus, yang ditunjukkan nilai $\varrho=0,216(\varrho>0,05)$. 
Ini berarti bahwa semakin sedikit penambahan tepung kedelai maka semakin tinggi kadar air.

Berdasarkan hasil penelitian menunjukkan bahwa menurunnya tingkat konsentrasi tepung kedelai menyebab-kan meningkatnya kadar air nugget ikan gabus. Peningkatan kadar air dapat disebabkan oleh $\mathrm{pH}$ daging. Menurut Soeparno (2005), DIA (Daya Ikat Air) akan meningkat bila $\mathrm{pH}$ daging lebih tinggi atau lebih rendah dari titik isoelektik proteinprotein daging. Pada $\mathrm{pH}$ yang lebih nugget ikan gabus dengan penambahan tepung kedelai $10 \%$ dan $15 \%$ sebanyak $56 \%$ panelis.

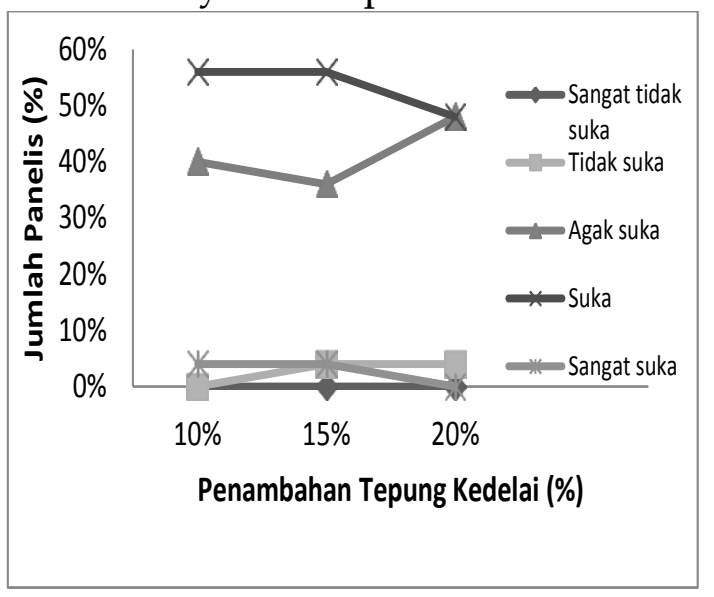

Gambar 1. Hasil Uji Organoleptik Warna Nugget Ikan Gabus

Tabel 1. Kadar Air Nugget Ikan Gabus dengan Penambahan Tepung Kedelai

\begin{tabular}{cccc}
\hline $\begin{array}{c}\text { Penambahan Tepung } \\
\text { kedelai }\end{array}$ & $\begin{array}{c}\text { Kadar Air (\%) dalam } \\
\mathbf{1 0 0} \mathbf{~ g r}\end{array}$ & Keterangan & Uji Anova \\
\hline $10 \%$ & 11 & $\mathrm{a}$ & \\
$15 \%$ & 10,6 & $\mathrm{a}$ & 0,216 \\
$20 \%$ & 10,5 & $\mathrm{a}$ & \\
\hline Keterangan : Huruf yang sama (a) pada keterangan menunjukkan tidak ada perbedaan nyata pada taraf & $5 \%$ \\
\multicolumn{2}{c}{ menurut uji LSD (@). }
\end{tabular}

rendah terdapat akses muatan positif yang mengakibatkan penolakan miofilamen dan memberi lebih banyak ruang untuk molekul-molekul air.

\section{Karateristik Organoleptik Warna}

Adapun presentase penerimaan panelis sebanyak 25 orang terhadap atribut warna pada nugget ikan gabus dengan variasi penambahan tepung kedelai $10 \%$, 15\%, dam $20 \%$ dapat dilihat pada Gambar 1. Berdasarkan hasil penelitian diketahui bahwa sebagian besar panelis memberikan penilaian suka (skor 4) pada warna
Berdasarkan hasil penelitian diketahui bahwa nugget ikan gabus dengan penambahan tepung kedelai $10 \%$ memilik nilai rata-rata tertinggi untuk mutu organoleptik (warna) nugget, dapat dilihat pada Tabel 2. Berdasarkan hasil Uji Kruskal Wallis penambahan tepung kedelai (10\%, $15 \%$ dan $20 \%$ ) tidak berpe-ngaruh secara signifikan terhadap warna nugget ikan gabus, yang ditunjukkan nilai $\varrho=0,510(\varrho>0,05)$. Ini berarti bahwa semakin sedikit penam-bahan tepung kedelai maka semakin tinggi tingkat kesukaan panelis terhadap 
ISSN $1978-3000$

Tabel 2. Nilai Rata-Rata Mutu Organoleptik (Warna) Nugget Ikan Gabus

\begin{tabular}{cccc}
\hline Penambahan Tepung Kedelai & $\begin{array}{c}\text { Nilai Rata-rata } \\
\text { Warna }\end{array}$ & Keterangan & $\begin{array}{c}\text { Uji Kruskal Wallis } \\
\text { (@) }\end{array}$ \\
\hline $10 \%$ & 40,14 & $\mathrm{a}$ & \\
$15 \%$ & 39,48 & $\mathrm{a}$ & 0,510 \\
$20 \%$ & 34,38 & $\mathrm{a}$ & \\
\hline Keterangan : Huruf yang sama (a) pada keterangan menunjukkan tidak ada perbedaan nyata pada taraf 5\% \\
menurut uji Kruskal Wallis (@).
\end{tabular}

mutu organo-leptik (warna) nugget ikan gabus.

Hal ini dikarenakan kandungan protein yang berasal dari ikan gabus dan tepung kedelai berperan dalam reaksi Maillard dan adanya proses pemanasan akan memberikan warna coklat pada saat nugget digoreng. Menurut Winarno (2008), reaksi Maillard merupakan reaksi antara karbohidrat, khususnya gula preduksi dengan $\mathrm{NH}_{2}$ dari protein menghasilkan senyawa hidroksimetilfur-fural yang kemudian berlanjut menjadi furfural. Furfural yang terbentuk kemu-dian membentuk senyawa melanoidin yang berwarna coklat.Melanoidin inilah yang memberikan warna coklat pada nugget.

\section{Rasa}

Adapun presentase penerimaan panelis sebanyak 25 orang terhadap atribut rasa pada nugget ikan gabus dengan variasi penambahan tepung kedelai $10 \%$, $15 \%$, dam $20 \%$, dapat dilihat pada Gambar 2. Berdasarkan hasil penelitian diketahui bahwa sebagian besar panelis memberikan penilaian suka (skor 4) pada rasa

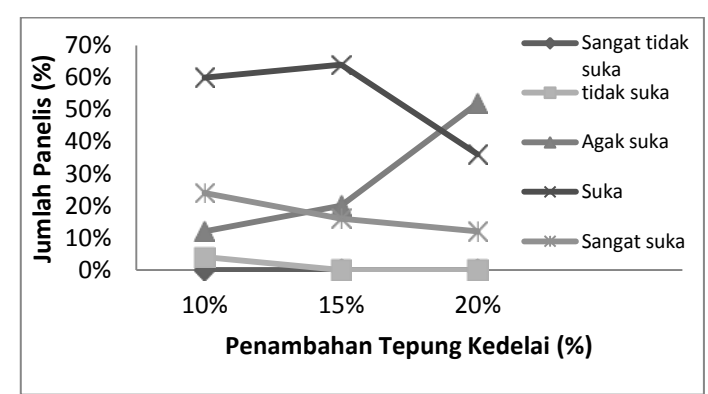

Gambar 2. Hasil Uji Organoleptik Rasa Nugget Ikan Gabus

nugget ikan gabus dengan penambahan tepung kedelai 15\% sebanyak $64 \%$ panelis.

Berdasarkan hasil penelitian dike-tahui bahwa nugget ikan gabus dengan penambahan tepung kedelai $20 \%$ memilik nilai rata-rata terendah untuk mutu organoleptik (rasa) nugget, dapat dilihat pada Tabel 3. Berdasarkan Uji Kruskall Walls diketahui bahwa variasi penambahan tepung kedelai $10 \%, 15 \%$ dan $20 \%$, berpengaruh signifikan terhadap rasa nugget ikan gabus, yang ditunjukkan dengan nilai $\varrho=0,035$ ( $\varrho<0,05)$. Ini berarti bahwa semakin banyak penambahan tepung kedelai, maka semakin rendah atau berkurangnya tingkat kesukaan panelis terhadap rasa nugget ikan gabus.

Berdasarkan penelitian diketahui bahwa mutu oragnoleptik 
(rasa) nugget ikan gabus dipengaruhi oleh penam-bahan variasi konsentrasi tepung kedelai.Hal ini dikarenakan nugget ikan gabus mengandung banyak protein yang dapat mempengaruhi rasa dari nugget ikan gabus. Menurut Winarno (2008), protein mengandung beberapa asam amino diantaranya adalah asam glutamat. Asam glutamat sangat penting perannya dalam pengolahan makanan, karena dapat menimbulkan rasa yang lezat.Ada bebrapa pendapat mengenai mekanisme kerja asam glutamat sehingga dapat menimbulkan cita rasa.Rasa daging mungkin disebabkan oleh hidrolisis protein dalam mulut.Asam glutamat meningkatkan cita rasa yang diinginkan sambil mengurangai rasa yang tidak diinginkan. Pendapat lainmengatakan bahwa asam glutamat memperbaiki keseimbangan cita rasa makanan olahan. Diutarakan juga asam glutamat menyebabkan sel reseptor rasa lebih peka sehingga dapat meningkatkan rasa dengan lebih baik.

\section{Tekstur}

Adapun presentase penerimaan panelis sebanyak 25 orang terhadap atribut tekstur pada nugget ikan gabus dengan variasi penambahan tepung kedelai 10\%, 15\%, dam 20\%, dapat dilihat pada Gambar 3. Berdasarkan hasil penelitian diketahui bahwa sebagian besar panelis memberikan penilaian suka (skor 4) pada rasa nugget ikan gabus dengan penambahan tepung kedelai 15\% sebanyak $60 \%$ panelis.

Berdasarkan hasil penelitian diketahui bahwa nugget ikan gabus dengan penambahan tepung kedelai $15 \%$ memilik nilai rata-rata tertinggi untuk mutu organoleptik (tekstur) nugget, dapat dilihat pada Tabel 4. Berdasarkan Uji Kruskall Walls diketahui bahwa variasi penambahan tepung kedelai $10 \%$, 15\% dan 20\%, berpengaruh signifikan terhadap tekstur nugget ikan gabus yang ditunjukkan dengan nilai $\varrho=0,009$ $(\varrho<0,05)$.

Tabel 3 Nilai Rata-Rata Mutu Organoleptik (Rasa) Nugget Ikan Gabus

\begin{tabular}{|c|c|c|c|}
\hline $\begin{array}{c}\text { Penambahan Tepung } \\
\text { Kedelai }\end{array}$ & Nilai Rata-rata Rasa & Keterangan & $\begin{array}{c}\text { Uji Kruskal } \\
\text { Wallis } \\
(\varrho)\end{array}$ \\
\hline $10 \%$ & 43,54 & a & \\
\hline $15 \%$ & 40,64 & a & 0,035 \\
\hline $20 \%$ & 29,82 & $\mathrm{~b}$ & \\
\hline
\end{tabular}




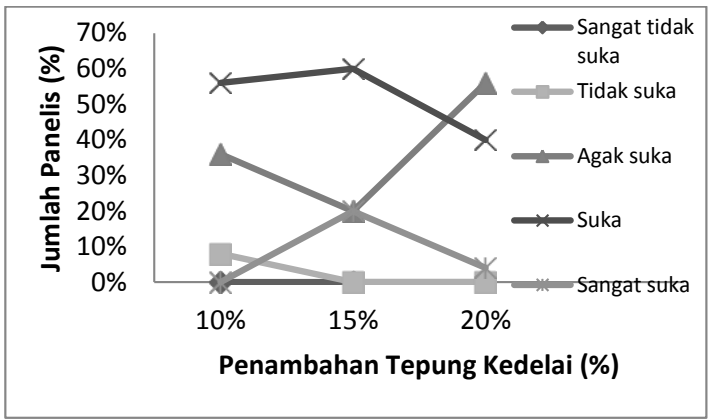

Gambar 3. Hasil Uji Organoleptik Tekstur Nugget Ikan Gabus

Berdasarkanpenelitian diketahui bahwa mutu oragnoleptik (tekstur) nugget ikan gabus dipengaruhi oleh penambahan variasi konsentrasi tepung kedelai.Hal ini dikarenakan nugget ikan gabus hanya menggunakan santan dan telur (sumber lemak) sebagai cairannya. Menurut Winarno (2008), penambahan lemak (santan dan telur) dimaksudkan untuk menambah kalori serta memperbaiki tekstur dan cita rasa makanan. Air yang terkandung dalam bahan makanan dapat mempengaruhi tekstur dan cita rasa makanan.Semakin sedikit air dalam bahan makanan, maka tekstur bahan makanan semakin keras.Didalam pembuatan nugget ikan gabus tidak menggunakan air tetapi hanya menggunakan santan dan telur sebagai penggati air atau cairan.

\section{SIMPULAN}

1. Penambahan tepung kedelai tidak berpengaruh terhadap kadar air nugget ikan gabus. Kadar air nugget tertinggi yaitu nugget ikan gabus dengan penambahan tepung kedelai $10 \%$.

2. Penambahan tepung kedelai tidak berpengaruh terhadap sifat organoleptik warna nugget ikan gabus. Warnanugget yang paling disukai yaitu nugget ikan gabus dengan penambahan tepung kedelai $10 \%$.

3. Penambahan tepung kedelai berpengaruh terhadap sifat organoleptik rasa nugget ikan gabus. Rasa nugget yang paling disukai yaitu nugget ikan gabus dengan penambahan tepung kedelai $10 \%$.

4. Penambahan tepung kedelai berpengaruh terhadap sifat organoleptik tekstur nugget ikan gabus. Tekstur nugget yang paling disukai yaitu nugget ikan gabus dengan penambahan tepung kedelai $15 \%$.

5. Nugget ikan gabus dengan penambahan tepung kedelai $10 \%$ merupakan penambahan yang paling ideal.

Tabel 4. Nilai Rata - Rata Mutu Organoleptik (Tekstur) Nugget Ikan Gabus

\begin{tabular}{cccc}
\hline $\begin{array}{c}\text { Penambahan Tepung } \\
\text { Kedelai }\end{array}$ & $\begin{array}{c}\text { Nilai Rata-rata } \\
\text { Tekstur }\end{array}$ & Keterangan & $\begin{array}{c}\text { Uji Kruskal Wallis } \\
(\rho)\end{array}$ \\
\hline $10 \%$ & 34,04 & $\mathrm{a}$ & \\
$15 \%$ & 47,80 & $\mathrm{a}$ & 0,009 \\
$20 \%$ & 32,14 & $\mathrm{~b}$ & \\
\hline
\end{tabular}

Keterangan: Huruf yang berbeda (b) pada keterangan menunjukkan ada perbedaan nyata pada taraf $5 \%$ menurut Uji Kruskal Wallis (Q). 


\section{DAFTAR PUSTAKA}

Almatsier, S., 2001. Prisip Dasar Ilmu Gizi. PT Gramedia Pustaka Utama, Jakarta.

Anonimous, 2005. DKBM (Daftar Komposisi Bahan Makanan). Persatuan Ahli Gizi Indonesia (PERSAGI), Jakarta.

Anonimous, Kedelai (Glycine max L).

Diakses dari

http://migroplus.com/brosur/

Budidaya\%20kedelai.pdf, 15

Oktober 2011.

Anonimous, Pemanfaatan Ikan

Gabus/Kutuk.Diakses dari

http://www.facebook.com/to

pic.php?uid=11919927477889

9\&topic=60, 19 Oktober 2011.

Anonimous, SNI (Standar Nasional

Indonesia) 01-6683-2002.

Diaksesdari

http://pustan.bpkimi.kemenp

erin.go.id/files/SNI\%2001-

6683-2002.pdf 15 Oktober 2011.

Astawan, M., 2004.Ikan yang sedap dan bergizi.Tiga serangkai, Solo.

Dena, 2011.Persiapan uji Organoleptik (1). Diakses dari http://yakacerdas.blogspot.co m/2011/03/persiapan-ujiorganoleptik-1.html, 03

November 2011.

Dena, 2011. Uji Kesukaan (Uji Hedonik). Diakses dari http://yakacerdas.blogspot.co m/2011/03/uji-kesukaan-uji- hedonik.html, 03 November 2011.

Ghufran, M.H., 2010. A to Z

Budidaya Biota Akuatik

untuk Pangan, Kosmetik dan

Obat-obatan, Penerbit

Andi.Diakses dari

file://D:/iTp/book ikan\%20g

abus.htm $\# \mathrm{v}=$ onepage\&q=ikan

\%20gabus\&f=false, 15

Oktober 2011.

Ginting, N., 2006. Penambahan Bahan Pengikat pada Nugget Itik Serati.Diakses dari

http://repository.usu.ac.id/bit stream/123456789/15155/1/ag p-apr2006-2.pdf, 11 Oktober 2011.

Kristiyanasari, W., 2010. Gizi Ibu Hamil. Nuha Medika, Yogyakarta

Latifah, 2010. Variasi Es Krim Terhadap Sifat Organoleptiknya. Diakses dari http://www.stppbogor.a.c.id, 15 Oktober 2011.

Manurung, R., 2005. Pengaruh Penambahan Bubuk Kedelai dan Sodium Poliposfat terhadap Mutu Nugget Ikan Cucut (Sphyraena Barracuda).Diakses dari http://repository.usu.ac.id/bit stream/123456789/15000/1/01 0305002.pdf, 15 Oktober 2011.

Nur, E., 2010. Hubungan antara Asupan Protein dengan Kekurangan Energi Kronik pada ibu Hamil. Diakses dari 
http://eprints.uns.ac.id/130/1/ 167080309201010381.pdf, 01 Desember 2011.

Nurbahri, W., 2011.Organoleptik. Diakses dari http://wimvynurbahri.blogsp ot.com/2011/06/organoleptik. html, 03 November 2011.

Nurjanah, dkk., 2005. Pengaruh penambahan bahan pengikat terhadap karateristik fisik otak-otak ikan sapu-sapu (Liposarcus pardalis).Diakses dari

http://repository.usu.ac.id/bit stream/123456789/15155/1/ag p-apr2006-2.pdf, 15 Oktober 2011.

Oktavia, Q., 2011. Pembuatan Abon Ikan Tuna dengan Penambahan Jamur Tiram. Karya Tulis Ilmiah, Politeknik Kemenkes, Bengkulu.

Priwindo, S., 2009.Pengaruh Pemberian Tepung Susu Sebagai Bahan Pengikat terhadap Kualitas Nugget Angsa.Diakses dari http://repository.usu.ac.id/bit stream/123456789/7604/1/09E 00567.pdf, 15 Oktober 2011.

Riwan, 2008.Sifat-sifat Organoleptik

Dalam Pengujian Terhadap Bahan Makanan. Diakses dari http://www.ubb.ac.id/menule ngkap.php?judul=Sifatsifat $\% 20$ Organoleptik\%20Dal am\%20Pengujian\%20Terhada p\%20Bahan\%20Makanan\&\& nomorurut artikel $=130,02$ November 2011.

Sakti, Arrs., 2008. Petunjuk Pengujian Organoleptik. Diakses dari http://smartsains.blogspot.co $\underline{\mathrm{m} / 2008 / 06 / \text { petunjuk- }}$ pengujian-organoleptik.html, 03 Novem-ber 2011.

Soeparno, 2005.Ilmu dan Teknologi

Daging. Gadjah Mada University Press, Yogyakarta.

Santoso, 2005. Teknologi Pengolahan Kedelai (Teori dan Praktek).

Diakses dari

http://labfpuwg.files.wordpre ss.com/2010/02/teknologipengolahan-kedelai-teoridan-praktek.pdf, 15 Oktober 2011.

Supariasa, IDN, dkk., 2001. Penilain Status Gizi. Buku Kedokteran EGC, Jakarta.

Tarwotjo C. S., 1998. Dasar-Dasar Gizi Kuliner. Penerbit PT Gramedia Widiasarana Indonesia, Jakarta.

Winarno F.G., 2008. Kimia Pangan danGizi. M-Biro Press, Bogor. 